\title{
Governance in Universities: The Institutional Performance Measurement System (IPMS)
}

\author{
Mohamed Meri Meri \\ Under-recruitment at Strasbourg University -France
}

\begin{abstract}
The higher education sector continues to be influenced by the market, as well as the continued pressures of lower government funding, and the need of citizens for easy access to educational services, and even with increased competition from international institutions. All these are the factors that determine the success of higher education institutions, and force the institutions to adapt quickly in an environment that requires a steady stream of satisfying educational services. Over the last decade, changes in funding and growing demands from students and donors have created a whole new model of higher education.This new trend has changed the way higher education institutions are run and operated, and the public's perception of them. Higher education institutions ,now, need to be managed more as public administrations or a business in the private sector. New models not largely dependent on public and government grants, but it is always based on accountability to the public and satisfy the needs of society. In some new model, higher education institutions must increasingly generate revenue, as does any private sector for profit corporation. Academics see universities as the engine of total progress. They transfer their intellectual productions to the institutions to meet the needs of society; University governance is making this progress. Here, University governance appears to be a necessary and precondition for deepening the independence of universities and institutions of higher education. This research shows the principles of this governance, methodology, models, comparisons between countries, and proposes a new model.
\end{abstract}

Key Words: University Governance, , Institutional Performance Measurement System.

\section{LITERATURE REVIEW}

The term "governance "began in its initial concept with (Jensen and Mackling - 12), which defined the term "corporate governance" in the context of solving institutional problems.

The (Executive Director of a Dutch company 1992) recognized the importance of good governance practices and the new administrative method in companies. The (Toronto Stock Exchange 1994) issued a report urges companies to include in their annual reports more information on the governance methods used. (Robert .M. Fabes and all -26). The (Leading investment and pension funds1994) in USA established guiding principles for good governance practices. The (Global Network of Good Governance1995) was established in institutions that adopted the first set of best corporate governance practices. California public employees ,retirement' system:Global Governance principles -3) . The (Center for European Policy Studies1995) published the methods of good governance in European companies (Marccus Partners-16 ). In 1996, (DAVIS) conducted a comparison between corporate governance practices in the five largest markets in the world (United States, Japan, Germany, France and United Kingdom). In 1999, a study by (LA PORTA et all-22 ) concluded that countries with legislation from Anglo-Saxon sources had the strongest practice of corporate and good governance, followed by countries that applied Germanic and Scandinavian civil law, the weakest practices exist in States that apply French law and it's like in Latin States. The ( leaders of the world's seven largest countries1999) called the International Monetary Fund (IMF) and the World Bank to assess the countries have applied new governance standards. 
Western countries (France, Italy, etc.), corporate governance practices began to take on great importance at the beginning of the 21st century (ORY. Jean- 24) . In 2003, (OECD) Analysis of Education Policies for Changing Governance Patterns in Higher Education. In Australia, (Mark Considine2003) present the relationship between Enterprise University \& New Governance Dynamics. (OCDE - 26).

In 2008, the (EC) made a study on the governance of higher education in Europe by analyzing governance structures, funding methods and their responsibilities in terms of academic staff. ( Eurydice-10) . In 2013, (Delotte Canada- 8) published a report on evolving higher education by proposing a governance model similar to the business model Deloite Canada 2013. (Thierry Côme- 5) addressed the governance of French universities in the journal management and public management. In 2014, the Center for Studies and Research on Qualifications presented a study to evaluate universities with a critique of institutional indicators. In 2015, (ERNST \& YOUNG and Associes- 9) conducted a study in France on higher education at the time of driving (Marie-Andrée Caron \& Hugues Boisvert-15). presented the management control and governance of the university: accounting as a discursive resource of performance.

\section{Research Objectives}

\section{RESEARCH OBJECTIVES, MAIN IDEA AND PROBLEMATIC}

The main objective of our research is to shed light on the concepts of university governance. And the sub-objectives are such:

1. Introduce the methodology to address this topic,

2. Enlighten applied models,

3. Comparisons between countries using this approach,

4. Propose a new practical model for university governance.

\section{Main idea:}

*Academics agree on the great importance of universities.

*Universities represent the driving force of total progress.

* Scientific factories transfer their intellectual productions to other institutions to meet the needs of society.

*Any attempt at university governance must adopt the methodology of management sciences.

*The methodology used for governance relies on highly qualified people to lead this project.

* University governance modeling helps to successfully complete this project.

* This research proposes a new practical model of university governance.

\section{The problematic}

Our work addresses the following issues and questions:

- What are the successful models when applying the University Governance project?

- Who are the actors in the successful project of university governance?

- How to develop and implement a practical model of university governance?

\section{METHODOLOGY}

The methodology followed by this research is the applied qualitative method, where the data sources were research and studies or books already published either by academics or researchers or by professionals working in the field of university governance. Reference was also made to reports or studies by European, UN, scientific organizations, etc. We made qualitative analyzes of the data collected to extract results, as well as present practical models of university governance applied in some developed countries by making descriptive 
comparisons. Finally, our model presents the Institutional performance measurement system (IPMS).

\section{GOVERNANCE FOR HIGHER EDUCATION \& ITS DETERMINANTS}

Governance appears to be a necessity and precondition for deepening the independence of universities and educational institutions. This requirement includes the ability to develop (Universities, Institutes, Schools,...), operational strategies, plans and programs by the actual specialists in university and research work, and to use resources and methods allocated, and real accountability based on the results achieved only.

\section{The determinants of academic governance:}

Numerous conferences have been held and leadership committees have been established at the national level in developed countries to develop determinants of academic governance that have presented topics that contribute to defining the pillars of academic governance. (JD.ASSIE -1).

Putting the mission of higher education in a changing social context and its implications for governance.

1. The needs for the educational systems governance.

2. The needs for the higher education institutions governance.

3. The needs for the participation of actors in higher education governance.

Emphasis was placed on the identification of academic management tools, strategic management, property and services management, taking into account the specificity and difficulties of universities, while developing appropriate conditions for change. Two factors have been placed at the forefront of the efforts to be undertaken:

1. Administrative feature: support in training and university administration.

2. Institutionalization: support in the implementation of reforms, the Scientific Council, evaluation of programs and projects, and institution-building.

The determinants that contribute to the building of academic governance are:

- Managing and modernization of universities and schools.

- Developing of evaluation culture (programs, modules for teaching and research, reliability procedures, teachers ....).

- Training of university administrators.

- Train the trainers.

- University educational support, and the use of new ICT.

- Strengthening research activities, through the preparation of the $\mathrm{PhD}$, and joint supervision of the university means.

- Search for new sources of university funding.

\section{ELEMENTS OF ACADEMIC GOVERNANCE SUCCESS:}

Some advanced international universities have made great efforts to implement academic governance. Their experiences have led to the adoption of some methodological and scientific foundations that represent the elements of success in implementing this approach, the most important of which are:

\section{Strategic Planning in the Management of Universities:}

Universities that have successfully implemented university governance have followed the strategic planning methodology by combining a combination of strategic planning, the ability to identify benchmarks and indicators, budget management and balanced score cards such as: 
Figure.1. Strategic Planning in the Management of Universities

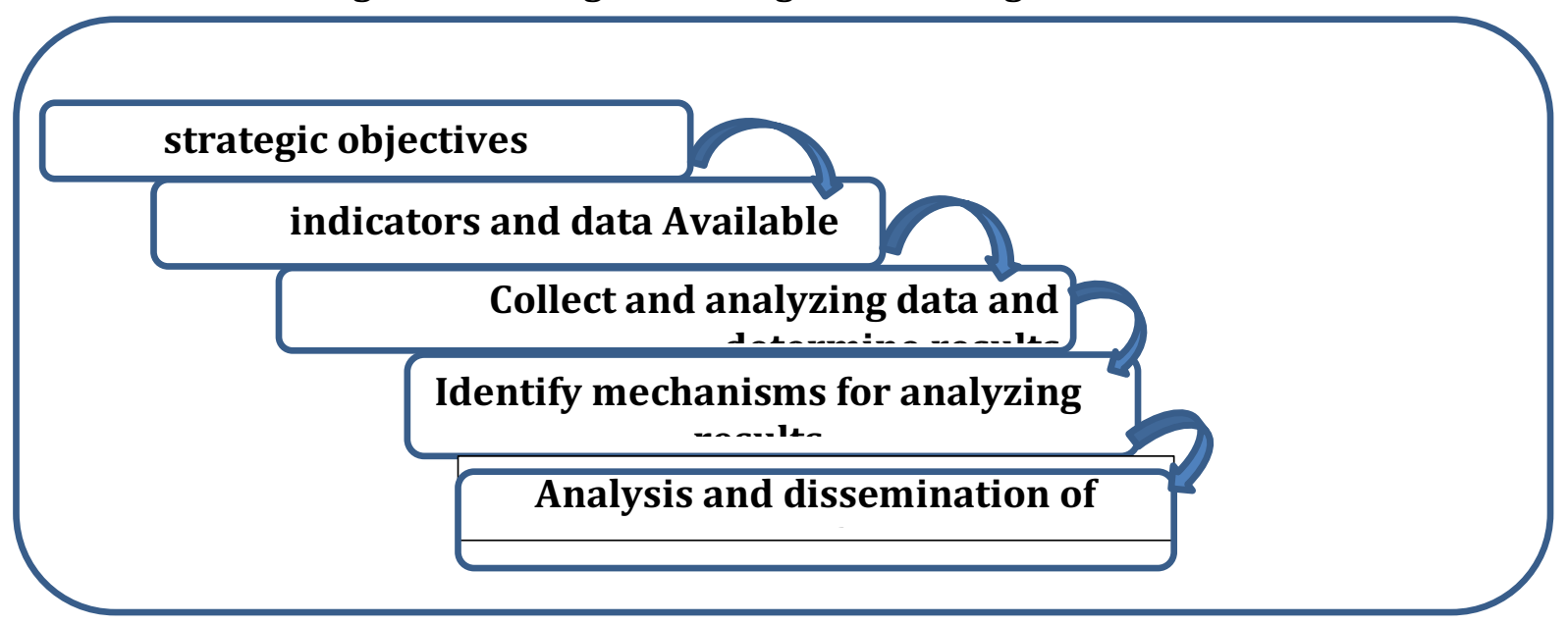

Source: (Kaplan, R. S. \& D. P. Norton -13 ).

\section{Integrated Performance System in Universities:}

Universities begin to implement an integrated system to achieve the adoption and successful application of the system of measuring institutional performance in universities as follows:

- The system covers all components of management in institutions whether productive, service or educational.

- A complex system of multidimensional nature with several work axes.

- A system that integrates with the strategic planning approach.

- A system that contains indicators of institutional performance that allow a real measurement of the performance of the institution.

- A system that facilitates relations with the internal and external environment of the organization.

- A system that reflects a Balance score cards that helps the leader to lead the organization he manages efficiently.

\section{UNIVERSITY GOVERNANCE MODELS}

These models are based on strategic management and Balanced score card technic adapted to universities.

The academic North Eastern Ohio University Model :

it is implemented in North Eastern Ohio University, College of Medecine and Pharmacy. Berkeley's Academic Mission and campus priorities. 
Figure.2. The academic North Eastern Ohio University Model

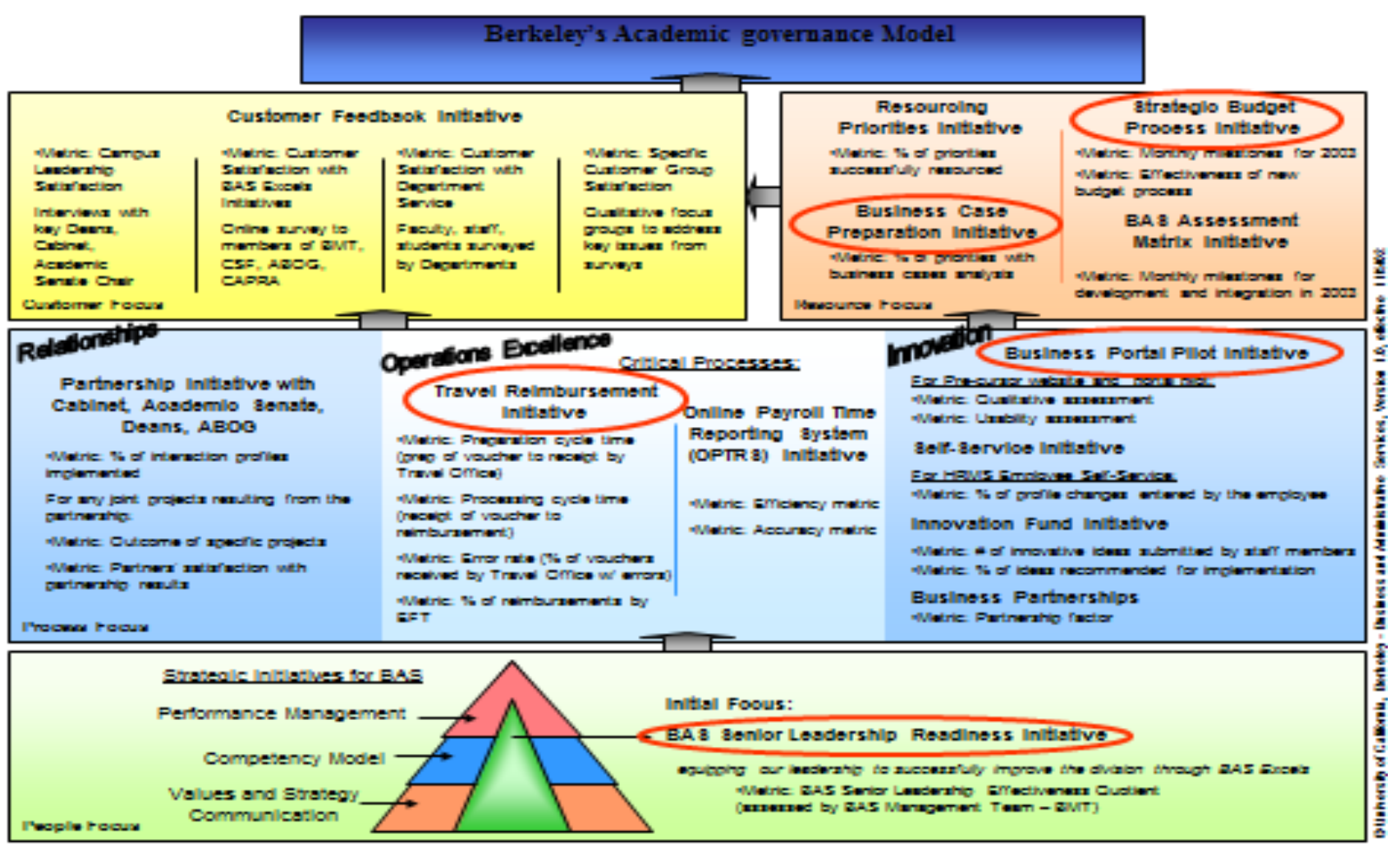

Source: (North Eastern Ohio University. WWW.neomed.edu).

\section{University of Ottawa Model:}

this model is invented and implemented by Ottawa University.

Figure.3. University of Ottawa Model

\section{The strategic plan \& the BS Cards}

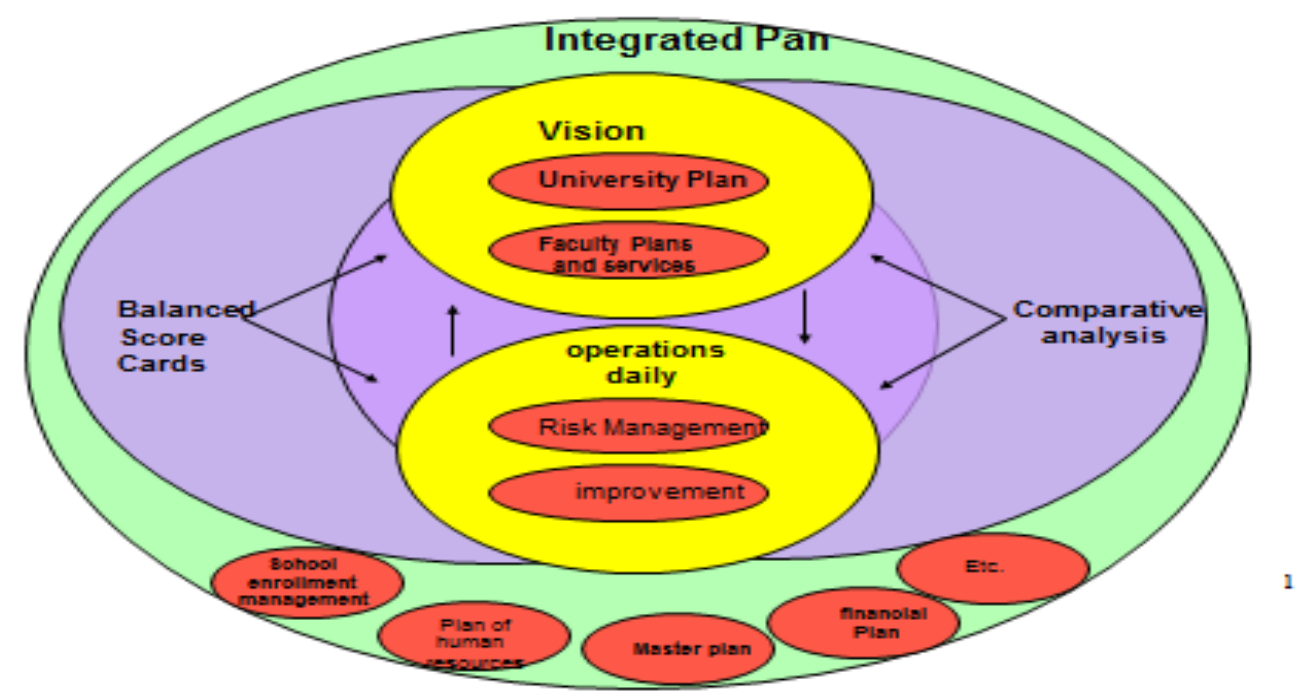

Source: (University of Ottawa. Uottawa.ca).

\section{Meri Model:}

this model is developped by Meri during a research project on cooperation beteween Damascus University \& Mohamed -5 Agdal University in Morocco, funded by (Agence de Francophonie) in 2007. 
Figure.4. Meri BSCard Universities Model

\section{Model for applying the (BSCard )in Universities}

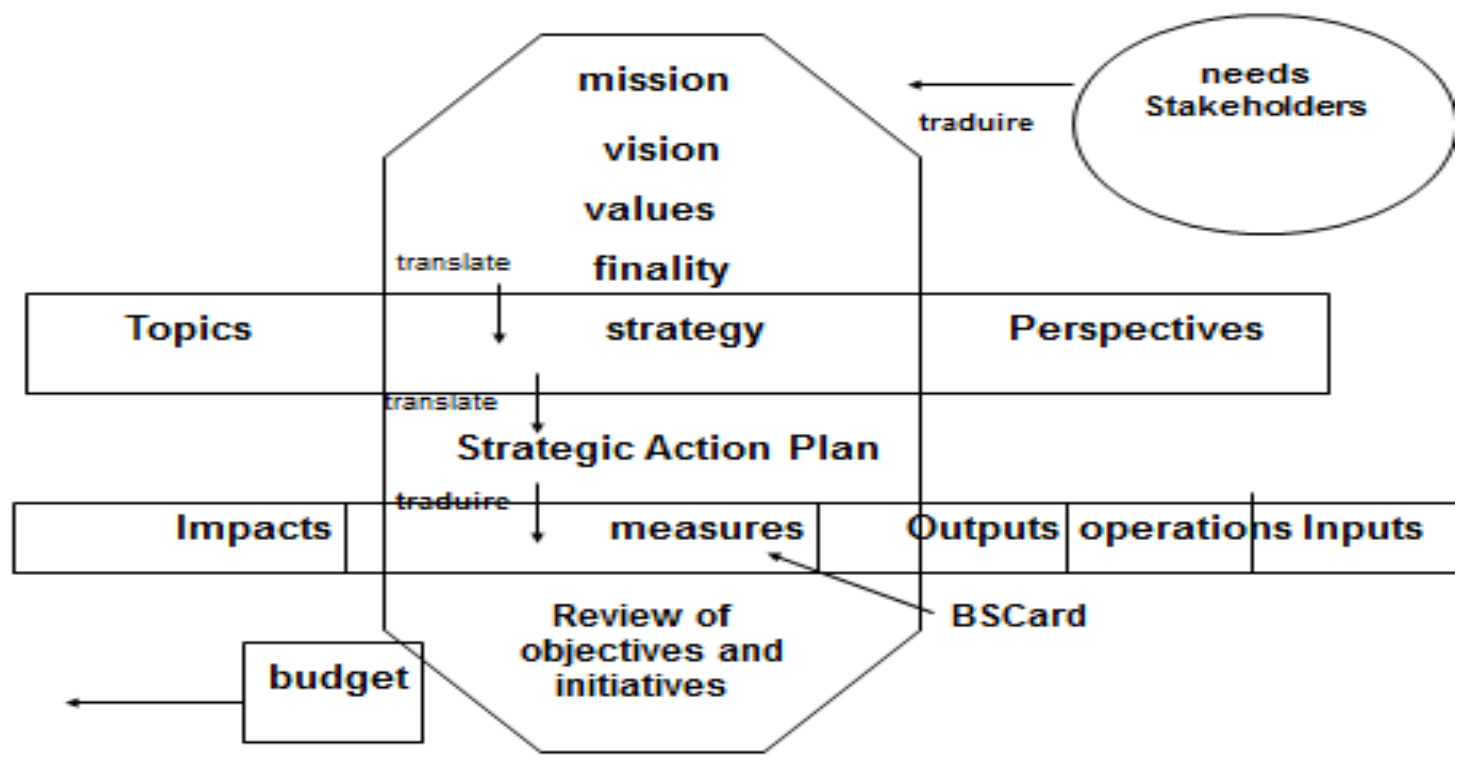

Source: ( Meri .Mohames meri .-13) .

\section{THE EXPERIENCES OF ACADEMIC GOVERNANCE}

There are several experiences related to the academic governance such as:

\section{European Experience Governance in Higher Education:}

The subject of the governance of higher education has become mainly linked to the great tasks of the Council of Europe: the defense of human rights, democracy and the rule of law. In 2003, the Steering Committee on Higher Education and Research (CDESR) approved a project: "Governance in Higher Education" for the three years 2004-2006. The initiative aimed to contribute to the European Year of Citizenship through Education, organized by the Council of Europe in 2005, For the Bologna track for 2005-2007.The aim of the program is to enhance the participation of students, administrators and other stakeholders in the governance of higher education. In the general context of the experiment, the most specific objectives were: ( J-M. TOULOUSE -27).

1- Presenting working documents and discussion space on the subject of governance of higher education.

2- Exploring the available research literature on the subject.

3- Organizing a conference on university governance in 2005.

4- Identify the areas of work available to the Council of Europe in a way that governs higher education.

5- Preparation of a concrete contribution to the 2007 Ministerial Conference.

The analysis of scientific literature goes beyond simple data collection, and also contains theoretical considerations that allow interpretation based on facts, data and the following points:

- Different approaches to goal / task formulation (based on information, special interests and academic objectives) and the relationship between public authorities, higher education institutions and civil society. 
- An overview based on legislative situations and practical cultures that includes features such as the relationship between the independence of faculties and the independence of the university.

- An overview and idea about the terms used to facilitate clarification.

- Changing the governance model through laws towards governance through integrated economy / finance independently.

\section{The experience of British universities:}

British universities have focused on university governance to strengthen their global leadership position in the ranking of universities after the United States of America and superior to European and Asian universities. Its universities focused on sharing three objectives:

1- Allow each person in the academic work to develop its competencies and complete the completion of its potential, personal and professional.

2- Developing his knowledge through scientific research.

3- To contribute to the economic success and cultural diversity of the nation.

These objectives cover the field of traditional university activities (education and research) and translate the central role of universities in the UK based knowledge economy.

The evolution of the work of academic governance is the development of the management of university institutions at the central level of the university and generally by the faculties, the level of research and education and reflects the form of governance of universities after 1992 as follows:

-The universities are composed of 92 members (the Board (the Board of Directors and the

Academic Committee).

- Mechanisms of the work of university administration:

- Organization of research and education activities

- funding universities.

The many sources of funding: financing education, difficult financial situation:

1- Policies, Evaluation Tools and Oversight: Main policies: knowledge transfer, access to universities, management improvement.

2- The system of supervision, evaluation and transparency

3- Independence in universities covers:

3-1 - Higher Education Market

3.2 Private funding and university autonomy

3.3 The case of British universities that raise some questions:

Have you taken advantage of communities? Have you taken advantage of the country?

- The relationship between education and research.

- Independence and good governance are key to the success of the British system

4. Future of university governance

4-1 - Reform research and education in universities.

4.2 International relations of universities. (Prost. Anne -24).

\section{The French Experience}

The Office of Accountancy in France noted several deficiencies, such as: weak computer operation, ineffective budget management procedures, limited control of financial management, weaknesses in internal operating costs, inefficient driving methods, and 
enhanced leadership tools, including university governance. Therefore, the Court of Accountancy paid great attention to university governance, studied the subject extensively, and presented Recommendations to the French Ministry of Higher Education and Scientific Research, which were included under the 2007 law and the most important four sets of recommendations are. (Cour des Comptes .Fr-7).

1. Increase the capacity of the management of the central organs of universities.

2. Allocating a comprehensive budget for universities.

3. Improving the capacity of the university administration.

4. Enhancing the role of contracting in university/ministry relations.

\section{Experience of the Francophone University Agency:}

The Agency held a seminar on university governance and discussed experiences on the challenges facing universities, the context of the knowledge society and globalization, governance and strategic planning issues, the practice of effective management, and evaluation of the quality of the university medium. (AUF -2).

1. the tasks of the African University compared to French.

2. Identify good practices.

3. Conduct regional consultations.

4. Analysis of the reality pension / status of universities.

5. Evaluation of quality management: publishing the quality charter, publishing the selfassessment manual, developing the accompaniment system with the intervention of the external expert, and developing training evaluation systems.

6. Reforming university programs: the commitment of universities to comprehensive reform in cooperation with other bodies, and the preparation of a practical guide to the formulation of programs and pedagogic foundations, and the organization of a workshop on the subject to prepare a man of change pedagogy, and the formation of a group of international experts on the subject.

7. the effectiveness of the administration: the implementation of training sessions on university administration, and cooperation with the World Bank on the subject.

8. Strategic planning: publication of a practical guide to support strategic planning, dissemination of local workshops to prepare for the practice of planning within the university framework, and implementation of a set of international regional actors to assist planning processes.

9. The problem of brain drain: a continuous evaluation of the programs according to their implications for brain drain, and the preference for joint work between institutions North/ South, and AUF can help about mental migration and participation in interuniversity/north-south experiments.

10. Issue and allocation of resources.

11. Relationship with the World Bank.

12. New role for university presidents.

13. The issue of university independence.

\section{Comparative Experiences: Lessons Learned: France, Germany and America?}

First, it is possible to analyze the internal operating methods of the internal guardianship authorities (the central departments of the Ministry in France / the Ministries of Regions in Higher Education in Germany / the agency responsible for higher education in every state in America) by presenting the following:

- The work of these authorities is directed towards university systems (France) or towards university institutions (Germany, America), and each option seems independent of the other. 
- Each of these options appears through communication and representation of interests, across criteria, decision-making logic, and very special leadership tools.

Second, it presents the preferred methods of organization for each country (Country) in line with the pattern of legislation concerning the Country's work in higher education.

Third, the dynamic between the method of action and the methods of legislation that correspond to them leads to a strong continuity of the observed form of organization.

Institutional design of the three cases: the observed differences between the three cases are based on two elements:

1. The work of public authorities towards universities or systems:

- Organization either by regulations or universities:

- France: Ministry of the Excavator to universities.

- Germany: provincial ministries ignore central regulations.

- America: Agency-oriented campus logic campus system.

- Dynamic decision procedures:

- France: the logic of central decisions.

- Germany: The decision is taken by each university institution.

- America: Management case / condition with respect for campus independence.

2. Tools used:

- General University Organization Tools:

- France: resort to public competitions / proceedings, advertising.

- Germany: Negotiation phase / stage.

- America: Collective Construction of Collective Standards. (MUSSELIN . C. -21).

\section{FINDINGS}

University governance appears to be a necessary and forward-looking condition for the success of universities to include the requirement to develop strategies, plans and operational programs by competent specialists while using the resources and resources allocated. As well as taking responsibility for achieving goals, and accounting practices in a real accountability based on the results achieved. The results of the research are:

1. The application of university governance in universities requires a period of preparation to disseminate the culture of university governance.

2. The approach requires the commitment of senior university officials in words and deeds, far from the slogan and narrow and timely interests.

3. The methodology shows that the change of traditional academic and administrative mindset is difficult to accept university governance.

4. Field Implementation, Principles and practices of academic governance require considerable effort by experts to pass ideas to execution.

5. The application of governance approach requires the participation of all those involved in the academic work (internal and external partners) in the application.

6. The implementation of the method of academic governance requires flexible legislation adapted to changes in the environment.

7. The availability of adequate budgets for universities is the essence of the application of university governance.

8. The system of selection of academic leaders (university presidents / deans / heads of departments / heads of laboratories,) is the success factor of academic governance.

9. The political will of the States concerned to apply university governance is the key to their application. 
10. Inventing practical models for applying university governance is the most important determinant of success.

\section{PRACTICAL MODEL PROPOSED}

As a results, this is the practical proposed model of university governance.

The model presented (IPMS) is schematized by a simple figure, used as a tool of academic institutional efficiency. The architecture of the model consists of four integrated stages such as:

1- The first: the administrative system, good construction and good application, including (strategic management, opening to the environment, administrative computing, supply management, financial management, human resources management, internal regulations, etc.).

2- The second: the Quality Assurance System, includes (Good products and services, Strong competitiveness, Effective operational management, Good relations with partners,).

3- The third: the system of self-evaluation, including (Evaluation of the whole university institution, evaluation of the development plan, products and services, partners, procedures and action plans, policy and strategy, evaluation of the components of the university institution, ..).

4- The fourth: The measurement of institutional performance, including:

* Internal components: Educational preparation (education, teachers, students, curriculum, resources,), Research and development (activities, researchers, center, products and services,), Management (human resources, finance, logistics, management information, information system, communication,).

* External components (Local and national (agreements, opening, activities, institutions, patents and products, projects, training, sales and purchases,), International (opening, joint ventures, active agreements, sales,). 
Figure .5. a Practical proposed model (University Governance)

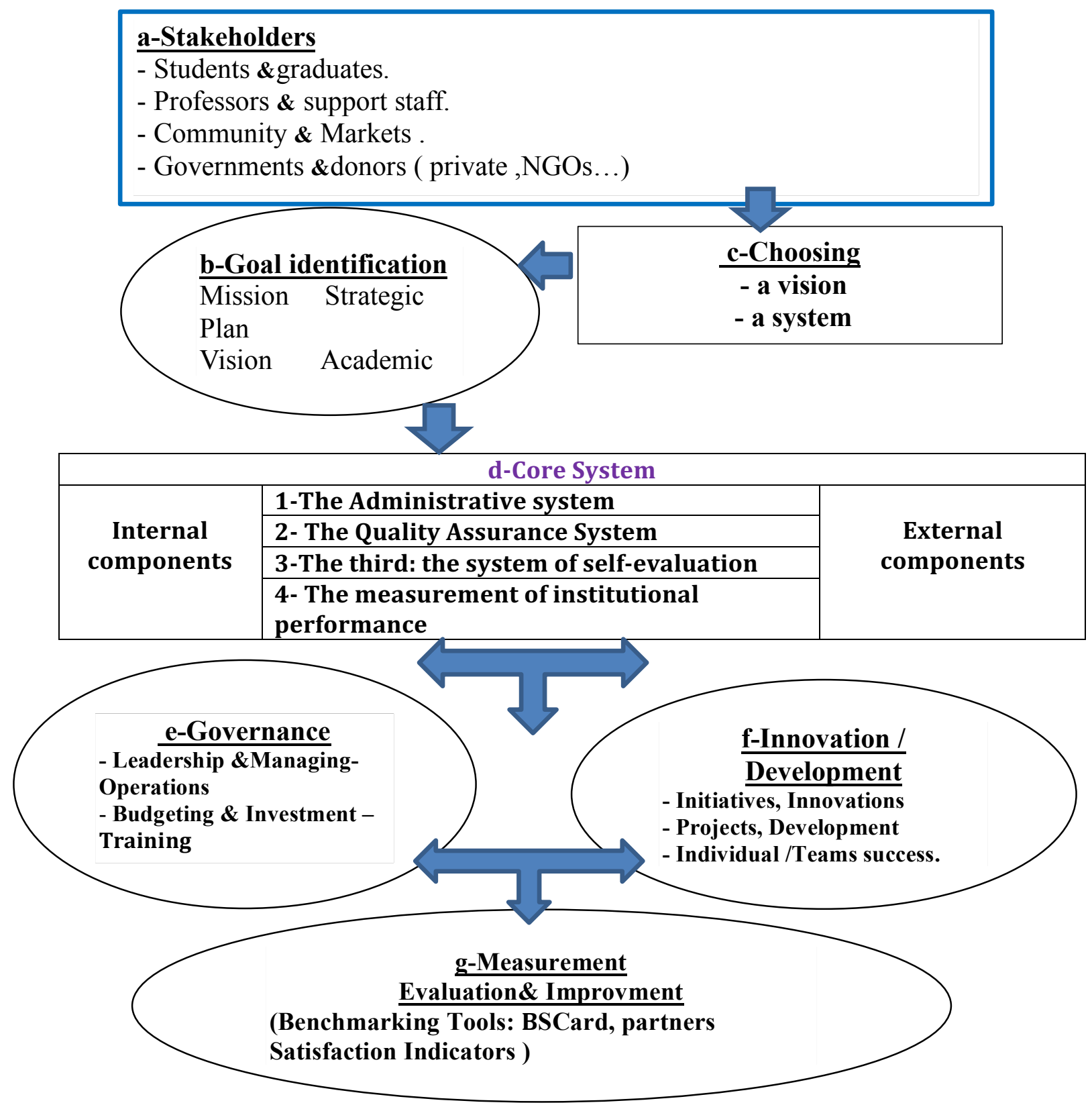

\section{CONCLUSION}

As a conclusion, Academics or researchers, all agree, as development specialists, on the great importance of higher education institutions. They consider that universities and scientific research centers represent the locomotive of continued growth and total progress.

University Governance - if it is understood and applied correctly - it is the only way to develop academic work. Universities that are still lagging behind those ranked high on the world university rankings, should be given opportunities to enter the pre-eminence of progress and academic development.

There are several practical models of University Governance applied in developed countries, those models need more development and adaptation to every country culture. Our model proposed- the University Performance Measurement System- (IPMS ) is a contribution .

This model (IPMS) is schematized by a simple figure used as a tool of academic institutional efficiency. It consists of four integrated stages with consecutive work steps, as mentioned in 


\section{the proposed model figure.}

Finally, this research is a new practical model to offer a scientific and practical contribution on this subject (Governance in Universities), for developing universities , and then economies and societies in general.

\section{References}

ASSIE .J-D, Renforcement de l'excellence universitaire, partenariat, relation avec les entreprises, AUF, 2006.

AUF , Séminaire la gouvernance universitaire : résumé des travaux, 15-19/12 /2003.

California public employees ,retirement' system:Global Governance principles , California Public Employees' Retirement System Lincoln Plaza 6- 400 Q Street - Sacramento, 2015,CA 95811.

CHEMS Consulting, A Final Report to the CUC on: Good practice in six Areas of the Governance of High Education Institutions, October 2004.

Côme .Thierry, La Gouvernance des Universites, AIRMAP , « Gestion et management public » , 2013/3 ,Volume $2 / n^{\circ} 1$ | pages 1 à 5 .

Considine. Mark, The Enterprise University \& New Governance Dynamics, The Public Management, Cambridge University Press .

Cour des Comptes, efficience et efficacités des universités :observation récentes et nouvelles approches, rapport 2005, France.

Deloite Canada , Higher education is evolving As the business model changes, the governance model must too. (2005) .www2.deloitte.com/ca/en/pages/human-capital/articles/higher-education-is-evolving.html.

ERNST \& YOUNG , Les établissements d'enseignement supérieur à l'heure du pilotage Les établissements d'enseignement supérieur à l'heure du pilotage,2015, ey.com/fr.

Eurydice, La gouvernance de l'enseignement supérieur en Europe, Unité européenne, Bruxelles, , Unité européenne. 2008. www.eurydice.org.

Harlam. Alan,\& All , Putting Community First in Social Innovation Education Putting Community First in Social Innovation ,Stanford Social Innovation Review , Jan. 4, 2017.

Jensen .William, Meckling. $\mathrm{H}$, Theory of the firm: Managerial behavior, agency costs and ownership structure,Journal of Finaancial Economics ,Volume 3,Issue4,October 1976,pages 305-360, https://doi.org/10.1016/0304-405X(76)90026-X.

Kaplan, R. S.\& Norton. D.P, The Strategy-Focused Organization: How Balanced Scorecard Companies Thrive in the New Business Environment. Boston, MA: Harvard Business School Press ,2001.

Larouche. Catherine \& All , La mesure différenciée de la performance des établissements au collégial et à l'université: validation d'une typologie des conceptions de l'enseignement supérieur, 2012, Université de Laval, Université de Québec, CREE.

Marie-Andrée Caron \& Hugues Boisvert, Contrôle de gestion et gouvernance de l'université : la comptabilité comme ressource discursive de la performance, France. 36ème congrès de l'AFC, May 2015, Toulouse,France.

Maher . Maria \& Andersson. Thomas, Corporate Governance :effects on firm performance and economic growth,Organization for economic , 1999, OECD .

Marccus Partners, The takeover Bids directive, Assessment Report, , Center for European Policy Studies, European Commission, Brussels ,2012.

Mayne . Eric , Corporate Governance Principles and Recommendations with 2010 Amendments , 2nd Edition , ASX Corporate Governance Council, August 2007.

Meri Mohamed meri, Système de mesure de la performance universitaire, modèle de tableau de bord équilibré, un projet de recherche en coopération entre l'université de Damas et L'université de Mohamed 5 Agdal, Bourse de AUF, décembre 2007.

MUSSELIN. C, régulation des systèmes universitaires : quelles leçons tirées de comparaison - France/ Allemagne/USA, 2001.

Musselin. Christine, La Grande course des universités, Business \& Economics , 2017. 
OCDE : Perspectives des politiques de l'éducation, Les réformes en marche: Les réformes en marche, OECD Publishing, Jan 19, 2015 - 356 pages.

LA PORTA .I.R. \& all , investor protection and corporate governance, truck school of business of Dartmouth, USA, 1999.

Prost . Anne, La gouvernance des universités britanniques, département science et technologie, à partir du rapport de stage de Mlle Céline Compagnon, publié le 27/11/2007.

ORY. Jean-Francis , Contrôle et pilotage de la performance globale des universités. Une approche par les parties prenantes : l'exemple du développement durable, l'Université de Reims Champagne-Ardenne, thèse 2015.

Robert .M. Fabes \& all , Toronto Stock Exchange ,Request for comments, Corporate Governance policy-proposed new disclosure, Requirement \& Amended Guidelines ,1994,Toronto.Canada.

TOULOUSE J-M :Rapport sur la gouvernance des institutions universitaires, HEC, monterial , 2007. 